\title{
Subcritical water hydrolysis of durian seeds waste for bioethanol production
}

\author{
Adi Purnomo ${ }^{1}$ Yulius Andy Wibowo Yudiantoro ${ }^{1}$ Jindrayani Nyoo Putro ${ }^{1} \cdot$ \\ Adi Tama Nugraha ${ }^{1} \cdot$ Wenny Irawaty $^{1} \cdot$ Suryadi Ismadji $^{1}$
}

Received: 18 February 2015/Accepted: 7 October 2015/Published online: 7 November 2015

(c) The Author(s) 2015. This article is published with open access at Springerlink.com

\begin{abstract}
The feasibility of bioethanol production using durian seed waste was investigated in this study. The effects of hydrolysis parameters (temperature, time, pressure and solid to water ratio) on the yields of reducing sugars and bioethanol were also examined. Central composite design was used to determine the optimum conditions of both reducing sugars yields obtained from hydrolysis stage and ethanol from reducing sugars fermentation. The optimized values for subcritical water process of durian seeds to produce reducing sugars were achieved at temperature of $139.8^{\circ} \mathrm{C}$; solid to water ratio of 1:30; pressure of $30 \mathrm{bar}$; and reaction time of $3.58 \mathrm{~h}$ with $32.37 \%$ yield of reducing sugars. The fermentation of $20 \mathrm{~g} \mathrm{~L}^{-1}$ reducing sugars for $72 \mathrm{~h}$ gave the highest ethanol concentration, i.e., $9.85 \mathrm{~g} \mathrm{~L}^{-1}$.
\end{abstract}

Keywords Durian seed - Bio-ethanol - Subcritical water · Hydrolysis

\section{Introduction}

Currently, the development of sustainable transportation fuels is a global challenge [1-3]. The burning of the fossil fuels produces many pollutant gases such as carbon dioxide, $\mathrm{NO}_{x}$, and $\mathrm{SO}_{x}$, causing severe environmental problems.

Wenny Irawaty

wenny_i_s@yahoo.com

Suryadi Ismadji

suryadiismadji@yahoo.com

1 Department of Chemical Engineering, Widya Mandala Catholic University Surabaya, Kalijudan 37, Surabaya 60114, Indonesia
Long-term fossil fuel availability issues also become a big concern; therefore, studies on alternative fuels derived from biomass, called bio-fuels, have gained much attention [4-8]. Depending on the type of the process, feedstock and stage of development, the production of biofuel can be classified into primary (first generation) and secondary (second and third generation) [9].

The production of first generation biofuel is primarily from food crops such as starchy crops (wheat, barley, corn, cassava, and potatoes), sugar crops (sugarcane, sugar beet, and sweet sorghum) and oil seeds $[2,10]$. In particular, the United States [11] and Brazil have commercially produced fuel ethanol from those kinds of biomasses [10]. However, the environmental issue and significant economic problems are tightly associated with the first generation of biofuel, the land area needed for growing the crops for bio-fuel production will be in competition with for food production, leading to severe food shortage problems $[11,12]$. In addition, the increase in the crop harvesting rates for biofuel production has also raised the concerns about the fertilizer and pesticide pollution, eutrophication, and carbon debt [13-15]. Therefore, due to those limitations of the first generation of biofuels, the second and third generation of biofuels have also been developed [14]. Low-cost agricultural residues (corn Stover, wheat straw) and agricultural by-products (rice hulls, corn fibre) have been explored as the potential raw materials for the biofuel production [2].

The third generation of biofuels is made from the biomass from non-arable land or water based on integrated technologies that produce feedstock as well as fuels. As for third generation of biofuel, microalgae with short harvesting cycles and can produce more oil yields (15-300 times) than traditional crops on area bases is thought as a new alternative to biofuel production history [9]. However, scaling up the production of biofuel from microalgae can face 
unsustainable demands on energy, water $(1 \mathrm{~L}$ biofuel: $3650 \mathrm{~L}$ water), and nutrients (nitrogen, phosphorus, and $\mathrm{CO}_{2}$ ) required for cultivating this particular feedstock [16]. Thus, this option is not currently feasible. Whereas a second generation of biofuels is considered the most viable one considering that lignocellulosic biomass as the main source of this biofuel is abundantly available in most countries in the world and not competing with food production [17].

As an agricultural country, Indonesia produces different kinds of agricultural products such as rice, fruits, vegetables, cassava, sweet potato, corn, soy, and sugar cane. One of the famous agricultural fruit products of Indonesia is durian. Currently, the capacity of durian production of Indonesia reaches more than 880,000 tons/year. The edible part of durian only 10-30\%, and it depends on the durian variety, the rest are shell (50-60\%) and seeds (10-20\%) which is discharged as waste. Durian seeds contain 50-70 \% carbohydrate, and currently have not been utilized as the source of carbohydrate in any food or starch production. Since it contains high amount of carbohydrate (amylose content is $20.8 \%$ ), in this study we utilized durian seeds as raw material for bioethanol production.

While attractive as an inexpensive and abundant feedstock, carbohydrate in durian seed must be converted into constituent sugar monomers prior to the bioethanol fermentation. So far, the conversion of carbohydrates into glucose can be achieved by acid hydrolysis as well as through enzymatic routes. However, the production cost is considered expensive since the methods require pretreatment, purification steps and often create environmental problems due to the use of acid catalyst and enzyme recovery $[18,19]$.

Subcritical water hydrolysis offers advantages to overcome the problems occur in acid and enzymatic hydrolysis by shortening the hydrolysis time and without using any catalyst. The subcritical water process has been widely used for hydrolyzing organic compounds [20-22], and in this paper we employed this method to hydrolyze carbohydrate from durian seed. To the best of our knowledge, there is no information about pretreatment of durian seeds using subcritical water process and subsequent used as precursor for bio-ethanol production. The objective of this study was to produce bioethanol from durian seeds. The effects of temperature, pressure, time, and ratio of durian seed to water on the yield of glucose and ethanol were studied.

\section{Methods}

\section{Materials}

Durian seeds were collected from local fruit markets in Surabaya. Prior to use, the durian seeds were repeatedly washed, sliced, and dried in an oven until the moisture content was around $5 \%$. The durian seeds were then pulverized in hammer mill to pass through a 170-200 mesh screen and stored at ambient temperature in tightly closed containers for further use. The chemical composition of dried durian seeds powder (flour) consisted of $89.45 \%$ carbohydrate, $5.32 \%$ moisture content, $4.25 \%$ protein, $0.68 \%$ fat, and $0.30 \%$ ash. The carbohydrate in the dried durian seeds powder was determined using enzymatic method (enzyme assay kit) [23]. The moisture content in the sample was analyzed by oven drying method at $105^{\circ} \mathrm{C}$. The protein content in the durian seeds powder was analyzed by micro Kjeldahl method [24]. The fat content was determined by Soxhlet extraction using petroleum ether at $65^{\circ} \mathrm{C}$, while the ash content was determined by burning of the durian seeds powder in muffle furnace at $800{ }^{\circ} \mathrm{C}$.

Chemicals used in this study were Fehling A solution ( $>99 \%$, Merck), Fehling B solution ( $>99 \%$, Merck), glucose $\left(>99 \%\right.$, Sigma-Aldrich $\left.{ }^{\circledR}\right)$, ethanol $(96 \%$, w/w in water, Merck) 3,5-dinitrosalicylic acid (98\%, SigmaAldrich $\left.{ }^{\circledR}\right)$, sodium potassium tartrate $(99 \%$, SigmaAldrich $\left.^{\circledR}\right)$, phenol $\left(99 \%\right.$, Sigma-Aldrich $\left.{ }^{\circledR}\right)$, sodium sulfite $\left(98 \%\right.$, Sigma-Aldrich $\left.{ }^{\circledR}\right)$, sodium hydroxide $(98 \%$, Merck), sulfuric acid (98\%, w/w in water, Merck), potassium dichromate $\left(99.5 \%\right.$, Sigma-Aldrich $\left.{ }^{\circledR}\right)$, and instant dry yeast $\left(\right.$ Fermipan $\left.^{\circledR}\right)$. All chemicals were used without any further treatment or purification process. The high-purity nitrogen gas (99.9 \%) was supplied by PT ANEKA GAS, Surabaya, Indonesia.

\section{Subcritical water hydrolysis}

The hydrolysis of durian seed flour in subcritical water was conducted in a high-pressure reactor system. The highpressure reactor system consists of $150 \mathrm{~cm}^{3}$ of stainless steel reactor (SS-316) with maximum temperature and pressure of $250{ }^{\circ} \mathrm{C}$ and 100 bar, respectively. The reactor was equipped with an external heater (ceramic band heater Type CF400, Thermotech Co., Ltd), a pressure gauge, a Type $\mathrm{K}$ thermocouple and M8 screws for tightening the reactor with its cap. A pre-determined amount of durian seed powder and distilled water were mixed (1:10, 1:20, and 1:30) and charged into the reactor. Subsequently, nitrogen gas was then flowed to the reactor to remove air and build a bit of pressure prior to heating. The reactor then was heated from room to the desired temperature (120, 140 , and $160{ }^{\circ} \mathrm{C}$ ) at heating rate of $20^{\circ} \mathrm{C} / \mathrm{min}$ and kept at the final temperature for 1,3 , and $5 \mathrm{~h}$. The pressure of the system was kept at 20, 30, and 40 bar. Following the hydrolysis, the solid material was separated using a centrifuge (Hettich, EBA 20) and the amount of reducing sugar in the supernatant was determined colorimetrically at $508 \mathrm{~nm}$ [25] by a spectrophotometer (Shimadzu, UV-VIS 
Table 1 Independent variables of CCD employed for durian seed powder hydrolysis in subcritical conditions

\begin{tabular}{|c|c|c|c|c|c|c|c|c|c|}
\hline \multirow[t]{2}{*}{ Run no. } & \multicolumn{4}{|l|}{ Variables } & \multicolumn{4}{|c|}{ Coded levels } & \multirow{2}{*}{$\begin{array}{l}\text { Response } \\
\text { Yield (\%) }\end{array}$} \\
\hline & $\begin{array}{l}\text { Time (h) } \\
t\end{array}$ & $\begin{array}{l}\text { Temperature }\left({ }^{\circ} \mathrm{C}\right) \\
T\end{array}$ & $\begin{array}{l}\text { Pressure (atm) } \\
P\end{array}$ & $\begin{array}{l}\text { Solid to water ratio }(-) \\
\text { SW }\end{array}$ & $t$ & $T$ & $P$ & SW & \\
\hline 1 & 1 & 120 & 20 & $1: 10$ & -1 & -1 & -1 & -1 & 2.49 \\
\hline 2 & 5 & 120 & 20 & $1: 10$ & +1 & -1 & -1 & -1 & 9.65 \\
\hline 3 & 1 & 160 & 20 & $1: 10$ & -1 & +1 & -1 & -1 & 1.52 \\
\hline 4 & 1 & 120 & 40 & $1: 10$ & -1 & -1 & +1 & -1 & 2.49 \\
\hline 5 & 1 & 120 & 20 & $1: 30$ & -1 & -1 & -1 & +1 & 3.34 \\
\hline 6 & 5 & 160 & 20 & $1: 10$ & +1 & +1 & -1 & -1 & 10.23 \\
\hline 7 & 1 & 160 & 40 & $1: 10$ & -1 & +1 & +1 & -1 & 1.52 \\
\hline 8 & 1 & 120 & 40 & $1: 30$ & -1 & -1 & +1 & +1 & 3.34 \\
\hline 9 & 5 & 120 & 40 & $1: 10$ & +1 & -1 & +1 & -1 & 9.65 \\
\hline 10 & 5 & 120 & 20 & $1: 30$ & +1 & -1 & -1 & +1 & 17.11 \\
\hline 11 & 1 & 160 & 20 & $1: 30$ & -1 & +1 & -1 & +1 & 2.27 \\
\hline 12 & 5 & 160 & 40 & $1: 10$ & +1 & +1 & +1 & -1 & 10.23 \\
\hline 13 & 1 & 160 & 40 & $1: 30$ & -1 & +1 & +1 & +1 & 2.27 \\
\hline 14 & 5 & 120 & 40 & $1: 30$ & +1 & -1 & +1 & +1 & 17.11 \\
\hline 15 & 5 & 160 & 20 & $1: 30$ & +1 & +1 & -1 & +1 & 16.42 \\
\hline 16 & 5 & 160 & 40 & $1: 30$ & +1 & +1 & +1 & +1 & 16.42 \\
\hline 17 & 5 & 140 & 30 & $1: 20$ & +1 & 0 & 0 & 0 & 25.27 \\
\hline 18 & 3 & 160 & 30 & $1: 20$ & 0 & +1 & 0 & 0 & 20.52 \\
\hline 19 & 3 & 140 & 40 & $1: 20$ & 0 & 0 & +1 & 0 & 30.87 \\
\hline 20 & 3 & 140 & 30 & $1: 30$ & 0 & 0 & 0 & +1 & 31.88 \\
\hline 21 & 1 & 140 & 30 & $1: 20$ & -1 & 0 & 0 & 0 & 3.24 \\
\hline 22 & 3 & 120 & 30 & $1: 20$ & 0 & -1 & 0 & 0 & 17.23 \\
\hline 23 & 3 & 140 & 20 & $1: 20$ & 0 & 0 & -1 & 0 & 30.87 \\
\hline 24 & 3 & 140 & 30 & $1: 10$ & 0 & 0 & 0 & -1 & 20.74 \\
\hline 25 & 3 & 140 & 30 & $1: 20$ & 0 & 0 & 0 & 0 & 30.87 \\
\hline 26 & 3 & 140 & 30 & $1: 20$ & 0 & 0 & 0 & 0 & 30.87 \\
\hline 27 & 3 & 140 & 30 & $1: 20$ & 0 & 0 & 0 & 0 & 30.87 \\
\hline 28 & 3 & 140 & 30 & $1: 20$ & 0 & 0 & 0 & 0 & 30.87 \\
\hline 29 & 3 & 140 & 30 & $1: 20$ & 0 & 0 & 0 & 0 & 30.87 \\
\hline 30 & 3 & 140 & 30 & $1: 20$ & 0 & 0 & 0 & 0 & 30.87 \\
\hline 31 & 3 & 140 & 30 & $1: 20$ & 0 & 0 & 0 & 0 & 30.87 \\
\hline
\end{tabular}

1201). The yield of reducing sugars was defined as the amount of reducing sugar obtained after the hydrolysis divided by the amount of durian seed flour used in the hydrolysis experiment (dry basis). The hydrolysis conditions were based on central composite design (CCD) with total of 31 experiments as shown in Table 1.

\section{Fermentation experiment}

Dry yeast (Saccharomyces cerevisiae from common baker's yeast) was employed in the fermentation studies and was routinely cultured on yeast extract peptone dextrose (YPD) agar plates $\left(20 \mathrm{~g} \mathrm{~L}^{-1}\right.$ glucose, $20 \mathrm{~g} \mathrm{~L}^{-1}$ peptone, $10 \mathrm{~g} \mathrm{~L}^{-1}$ yeast extract, and $16 \mathrm{~g} \mathrm{~L}^{-1}$ agar) at $30{ }^{\circ} \mathrm{C}$. A small-scale culture was prepared by inoculating a single colony of $S$. cerevisiae into a medium containing $20 \mathrm{~g} \mathrm{~L}^{-1}$ glucose, $20 \mathrm{~g} \mathrm{~L}^{-1}$ peptone, and $10 \mathrm{~g} \mathrm{~L}^{-1}$ yeast extract. After $24 \mathrm{~h}$, the culture was removed into fermentation media, the ratio of the culture with fermentation media was 1:10 (v/v). Fermentation experiment was carried out in micro-aerobic and aerobic conditions in a $250 \mathrm{~mL}$ flask at $\mathrm{pH} 5.0 \pm 0.5$ and $30{ }^{\circ} \mathrm{C}$ under slow and constant agitation (100 rpm). The concentrations of the reducing sugars used in the fermentation experiments were 10,15 , and $20 \mathrm{~g} \mathrm{~L}^{-1}$, while the time for fermentation experiments were 24,48 , and $72 \mathrm{~h}$. The concentration of reducing sugars in the fermentation experiments was adjusted to the desired concentration (20 $\mathrm{g} \mathrm{L}^{-1}$ ) by addition of glucose. Two variables CCD was 
Table 2 Independent variables of CCD employed of ethanol production

\begin{tabular}{|c|c|c|c|c|c|}
\hline \multirow[t]{2}{*}{ Run no. } & \multicolumn{2}{|l|}{ Variables } & \multicolumn{2}{|c|}{ Coded levels } & \multirow{2}{*}{$\begin{array}{l}\text { Respons } \\
\text { Ethanol } \\
\left(\mathrm{g} \mathrm{L}^{-1}\right)\end{array}$} \\
\hline & $\begin{array}{l}\text { Reducing sugars concentration } \\
\left(\mathrm{g} \mathrm{L}^{-1}\right) \\
S\end{array}$ & $\begin{array}{l}\text { Time }(\mathrm{h}) \\
t_{\mathrm{F}}\end{array}$ & $S$ & $t_{\mathrm{F}}$ & \\
\hline 1 & 20 & 72 & +1 & +1 & 11.76 \\
\hline 2 & 20 & 24 & +1 & -1 & 6.86 \\
\hline 3 & 10 & 72 & -1 & +1 & 5.37 \\
\hline 4 & 10 & 24 & -1 & -1 & 3.87 \\
\hline 5 & 10 & 48 & -1 & 0 & 5.44 \\
\hline 6 & 15 & 24 & 0 & -1 & 4.81 \\
\hline 7 & 20 & 48 & +1 & 0 & 11.76 \\
\hline 8 & 15 & 72 & 0 & +1 & 7.89 \\
\hline 9 & 15 & 48 & 0 & 0 & 7.97 \\
\hline 10 & 15 & 48 & 0 & 0 & 7.97 \\
\hline 11 & 15 & 48 & 0 & 0 & 7.97 \\
\hline 12 & 15 & 48 & 0 & 0 & 7.97 \\
\hline 13 & 15 & 48 & 0 & 0 & 7.97 \\
\hline
\end{tabular}

\section{Results and discussion}

\section{Hydrolysis of durian seed powder in subcritical conditions}

\section{Model for hydrolysis}

Time, temperature, pressure, and solid to water ratio were examined as factors that might affect the yield of reducing sugars. From the general analysis, it is possible to select variables and interactions that are significant in the confidence range of 90-95\%. The significant values from Student's $t$ distribution (obtained from ANOVA) were employed to determine the significance of the regression model. The linear and full quadratic models are given as follow:

$Y=16.91+6.10 t-0.11 T-0 P+2.34 \mathrm{SW}$

and

$$
\begin{aligned}
S= & 29.54+6.09 t-0.06 T+0 P+2.31 \mathrm{SW}-13.79 t^{2} \\
& -9.17 T^{2}+2.83 P^{2}-1.74 \mathrm{SW}^{2}+0.24 t \cdot T-0 T \cdot P \\
& +0 t \cdot P+1.51 t \cdot \mathrm{SW}-0.17 T \cdot \mathrm{SW}+0 P \cdot \mathrm{SW}
\end{aligned}
$$

where $S$ is the reducing sugars yield, $t, T, P$, and $\mathrm{SW}$ are time, temperature, pressure, and solid to water ratio, respectively. The analysis of the experimental data using linear model gave poor $R^{2}(0.1844)$.

The $p$ value of the quadratic model $(<0.0001)$ was quite significant at the probability level of $5 \%\left(R^{2}=0.9602\right)$. In this study, the first-order effects of hydrolysis time, temperature, and solid to water ratio were significant at the confidence level of $95 \%$. However, the interactions between pressures, solid to water ratios, time and pressure, 
temperature and pressure, and pressure and solid to water ratio were insignificant. Re-arrangement of Eq. (2) with the inclusion only the significant parameters give the following result:

$$
\begin{aligned}
S= & 29.74+6.09 t-0.06 T \\
& +2.31 \mathrm{SW}-12.95 t^{2}-8.33 T^{2}-0.89 \mathrm{SW}^{2}+1.51 t \cdot \mathrm{SW}
\end{aligned}
$$

The ANOVA analysis of Eq. (3) gave the results as summarized in Table 3. The results show that the $p$ value of the model is significant $(<0.0001)$ and a good fitting of the model with the experimental data is also observed $\left(R^{2}=0.9564\right)$.

The effects of hydrolysis operating parameters on the reducing sugars yield are plotted as contour plots as shown in Fig. 1. By comparing the generated plots in Fig. 1, it can be seen that the highest value of solid to water ratio $(+1)$ had a tendency to increase the yield of reducing sugars. Higher solid to water value increase the yield due to more carbohydrate is available and the breakdown of carbohydrate will produce reducing sugars. On the other hand, by increasing the temperature ( 0 ) and time $(0)$ of hydrolysis of durian seed until certain values $\left(140{ }^{\circ} \mathrm{C}\right.$ and $\left.4 \mathrm{~h}\right)$, has the tendency to enhance the reducing sugars yield.

The effect of solid to water ratio on the yield of reducing sugars can be observed as a function of time and temperature as shown in Fig. 2. At hydrolysis time of $1 \mathrm{~h}$, the reducing sugars yield was observed around $2.9 \%$. By increasing the hydrolysis time to 3 and $5 \mathrm{~h}$, the reducing sugars yield increased up to around $31 \%$. With the increase of hydrolysis time, the contact between the carbohydrate molecules and the ionic product of water $\left(\mathrm{H}_{3} \mathrm{O}^{+}\right.$ and $\mathrm{OH}^{-}$) become more intense and longer, and more of the carbohydrate molecules were hydrolyzed and converted into monomeric sugars. At subcritical condition, water acts as an acid or base catalyst because of the presence of $\mathrm{H}_{3} \mathrm{O}^{+}$ and $\mathrm{OH}^{-}$at higher concentration than in ambient temperature [27]. Subcritical water, therefore, has better catalytic activity to breakdown the complex carbohydrate molecules into simple sugar molecules. Further increase of hydrolysis time to $5 \mathrm{~h}$, the reducing sugars yield decreased as indicated in Fig. 2. The decrease of the yield of reducing sugars mainly due to the dehydration of reducing sugars into other products such as humins, furfural, hydroxymethyl furan (HMF), and levulinic acid [28].

It has been known that the temperature has the positive effect on the hydrolysis process. By increasing temperature, the breakdown of water molecules into the ionic products also increase leading to the increase of the $\mathrm{H}_{3} \mathrm{O}^{+}$ concentration. The water become more reactive and more carbohydrate molecules were converted into monomeric sugars. However, at temperature higher than $140{ }^{\circ} \mathrm{C}$, the dehydration reaction of monomeric sugars into 5-(hydroxymethyl)furfural and levoglucosan also increase; these side reactions decreased the yield of monomeric sugars.

Based on the experimental results as well as ANOVA analysis, the pressure was found to have insignificant effect on the yield of reducing sugars. In general, the yield of reducing sugars was not affected by the change of pressure. In the subcritical process, the pressure has a role to maintain water at its liquid state, since the hydrolysis process occurs in liquid phase [29].

Maximizing the product yield is an important point to establish an efficient process, and it can be achieved through the setting of all significant parameters at optimum conditions. Figure 3 depicts the optimum condition of each significant parameter in the durian seed hydrolysis in subcritical conditions. The optimum conditions for hydrolysis of durian seed were $0.2929,-0.0101$, and 1.0
Table 3 Analysis of variance for regression on CCD model of reducing sugars production

\begin{tabular}{lccccc}
\hline Statistical parameter & Sum of squares & Degrees of freedom & Mean square & $F$ ratio & $p$ value \\
\hline Regression model of CCD & 4028.04 & 14 & & & \\
Model & 116.33 & 16 & 287.72 & 39.560 & $<0.0001$ \\
Residual & 116.33 & 10 & 7.27 & & \\
Lack-of-fit & 0.00 & 6 & 11.63 & 0.050 & 0.050 \\
Pure error & & 30 & 0.00 & & \\
Total & 0.9474 & & & & \\
$R^{2}$ & 4005.92 & 7 & & & \\
Screening regression model of CCD & 138.45 & 23 & 572.27 & 95.070 & $<0.0001$ \\
Model & 138.45 & 7 & 6.02 & & \\
Residual & 0.00 & 16 & 0.050 & & \\
Lack-of-fit & & 30 & & & \\
Pure error & 0.9564 & & & & \\
Total & & & & & \\
$R^{2}$ & & & & & \\
\hline
\end{tabular}



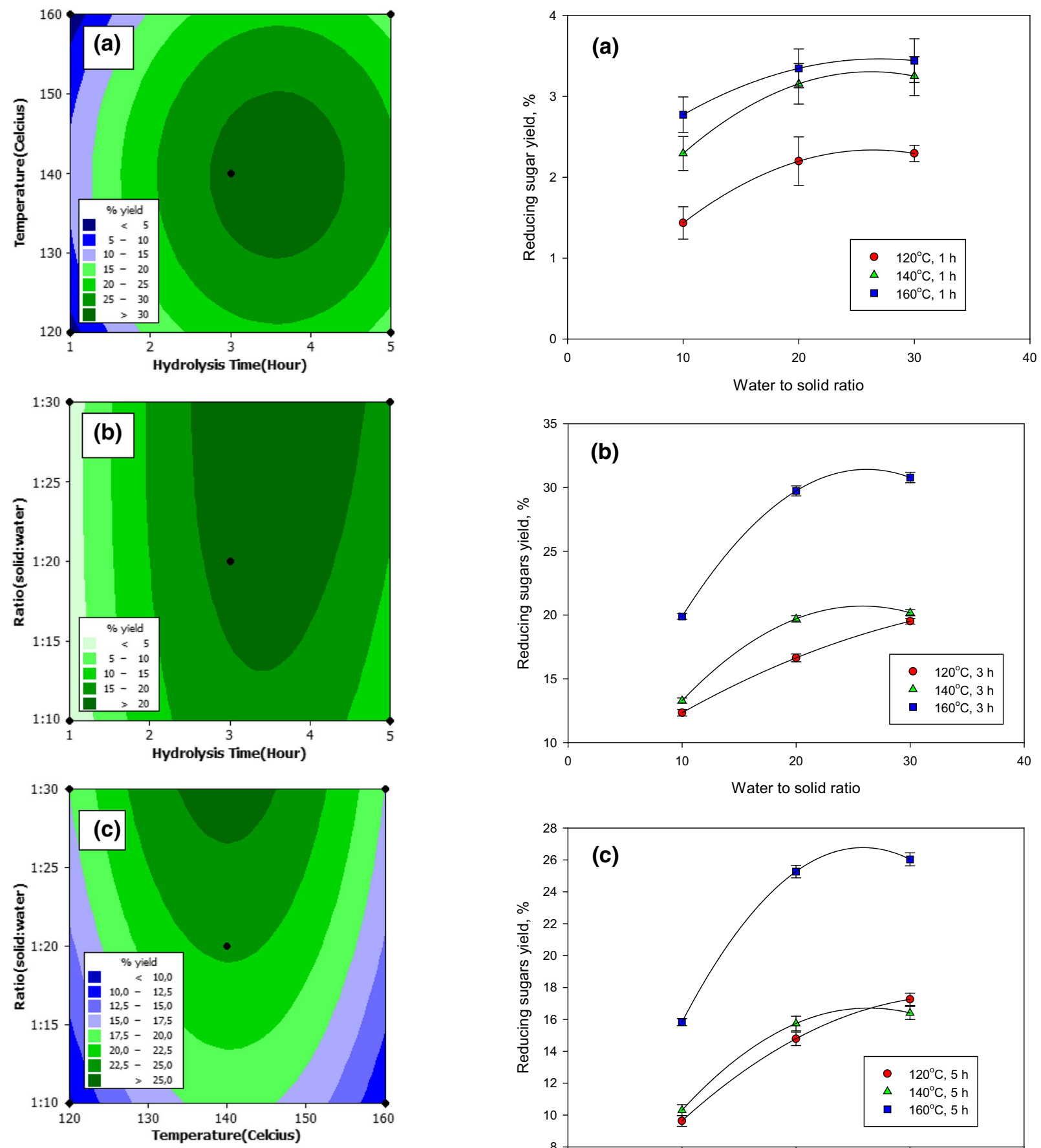

Fig. 1 Contour plots of selected independent variables of durian seed hydrolysis on the reducing sugars yield. a Hydrolysis time versus temperature, $\mathbf{b}$ hydrolysis time versus ratio, and $\mathbf{c}$ temperature versus ratio

coded unit for parameters of time, temperature, and solid to water ratio, respectively.

These units correlate to solid to water ratio of 1:30, hydrolysis temperature of $139.8^{\circ} \mathrm{C}$, and hydrolysis time of $3.58 \mathrm{~h}$. The optimum sugar yield is $32.37 \%$ with 0.978 precision.

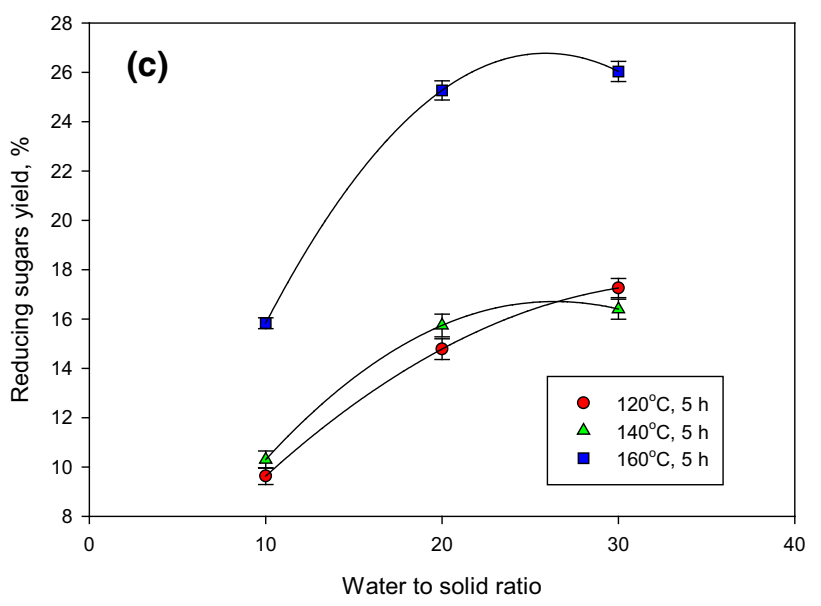

Fig. 2 Effect of time on the yield of reducing sugars, a $1 \mathrm{~h}, \mathbf{b} 3 \mathrm{~h}$, and $\mathbf{c} 5 \mathrm{~h}$

\section{Fermentation of sugars to ethanol}

The fermentation of reducing sugars into bio-ethanol was modeled using full quadratic polynomial model with the independent variables: reducing sugars concentration and fermentation time. Table 4 shows the 
Fig. 3 Independent factor optimization during subcritical water hydrolysis of durian seed

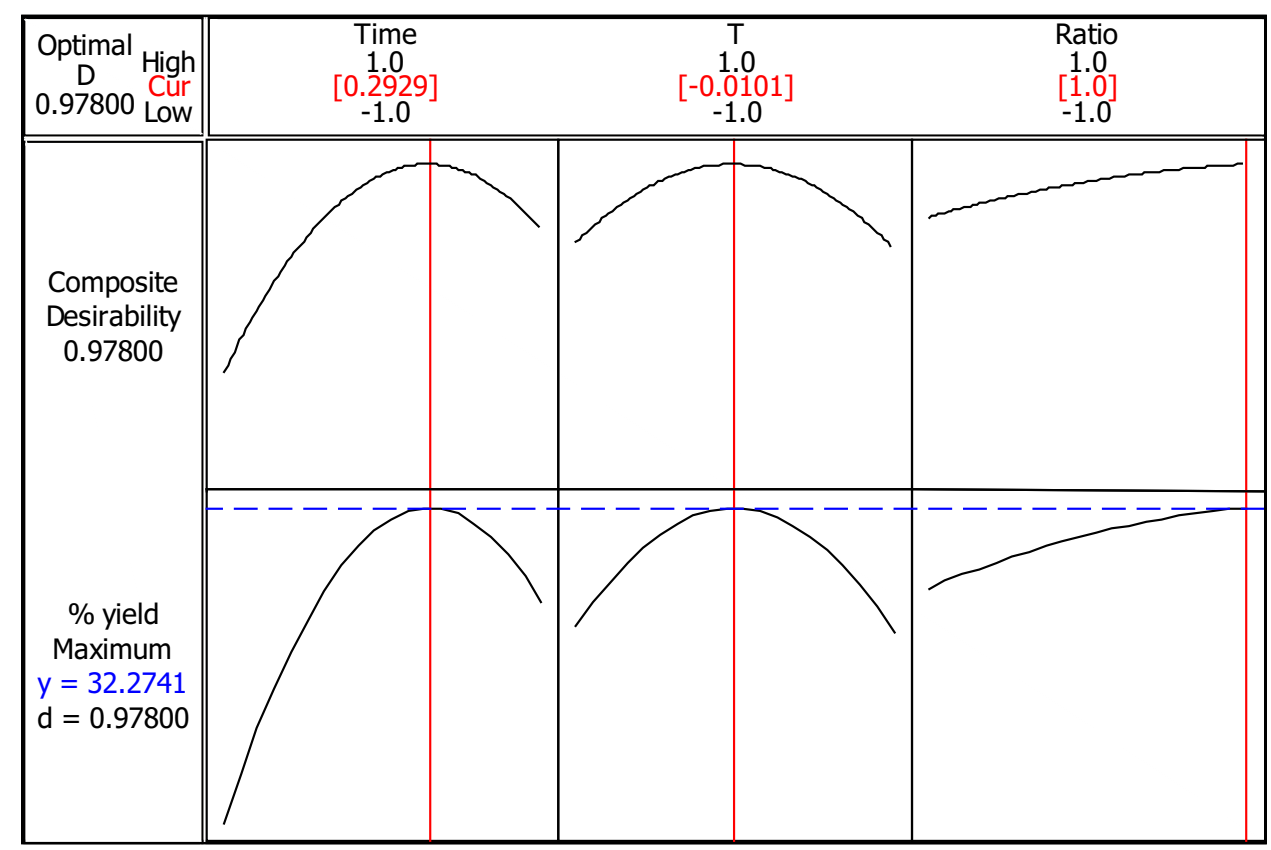

\begin{tabular}{lcclrl}
\hline Effects & Sum of squares & Degrees of freedom & Mean square & $F$ ratio & $p$ value \\
\hline \multicolumn{2}{l}{ Analysis of variance for ethanol production } & & & \\
$S$ & 29.6148 & 1 & 29.6148 & 764.06 & 0.000 \\
$t_{\mathrm{F}}$ & 6.5731 & 1 & 6.5731 & 169.59 & 0.000 \\
$S \cdot S$ & 0.7315 & 1 & 0.7315 & 18.87 & 0.003 \\
$t_{\mathrm{F}} \cdot t_{\mathrm{F}}$ & 2.9321 & 1 & 2.9321 & 75.65 & 0.000 \\
$S \cdot t_{\mathrm{F}}$ & 0.7482 & 1 & 0.7482 & 19.30 & 0.003 \\
Total & 40.3211 & 12 & $R^{2}=0.9932$ & & \\
Regression model & of CCD & & & & \\
Model & 39.9164 & 5 & 7.9833 & 205.97 & $<0.0001$ \\
Residual & 0.2713 & 7 & 0.0388 & & \\
Lack-of-fit & 0.2324 & 3 & 0.0776 & & \\
Pure error & 0.0389 & 4 & 0.097 & & \\
$R^{2}$ & 0.9932 & & & &
\end{tabular}

Table 4 Analysis of variance for ethanol production $(E)$ as a function of reducing sugars concentration $(S)$ and time of fermentation $\left(t_{\mathrm{F}}\right)$, and regression model of CCD from the fermentation process of reducing sugars from durian seed can be written by the following equations (linear and quadratic forms):

$E=7.51+2.62 S+1.58 t_{\mathrm{F}}$

and

$E=7.97+2.62 S+1.58 t_{\mathrm{F}}+0.62 S^{2}-1.62 t_{\mathrm{F}}^{2}+0.85 S \cdot t_{\mathrm{F}}$

where $E$ is the ethanol concentration, $S$ and $t_{\mathrm{F}}$ are reducing sugars concentration and fermentation time, respectively. The linear form model gave low value of $R^{2}(0.8351)$, a strong indication that the linear form could not represent the experimental data well. 
Fig. 4 Contour plot (top) and response surface (bottom) of the reducing sugars concentration and fermentation time on the yield of ethanol

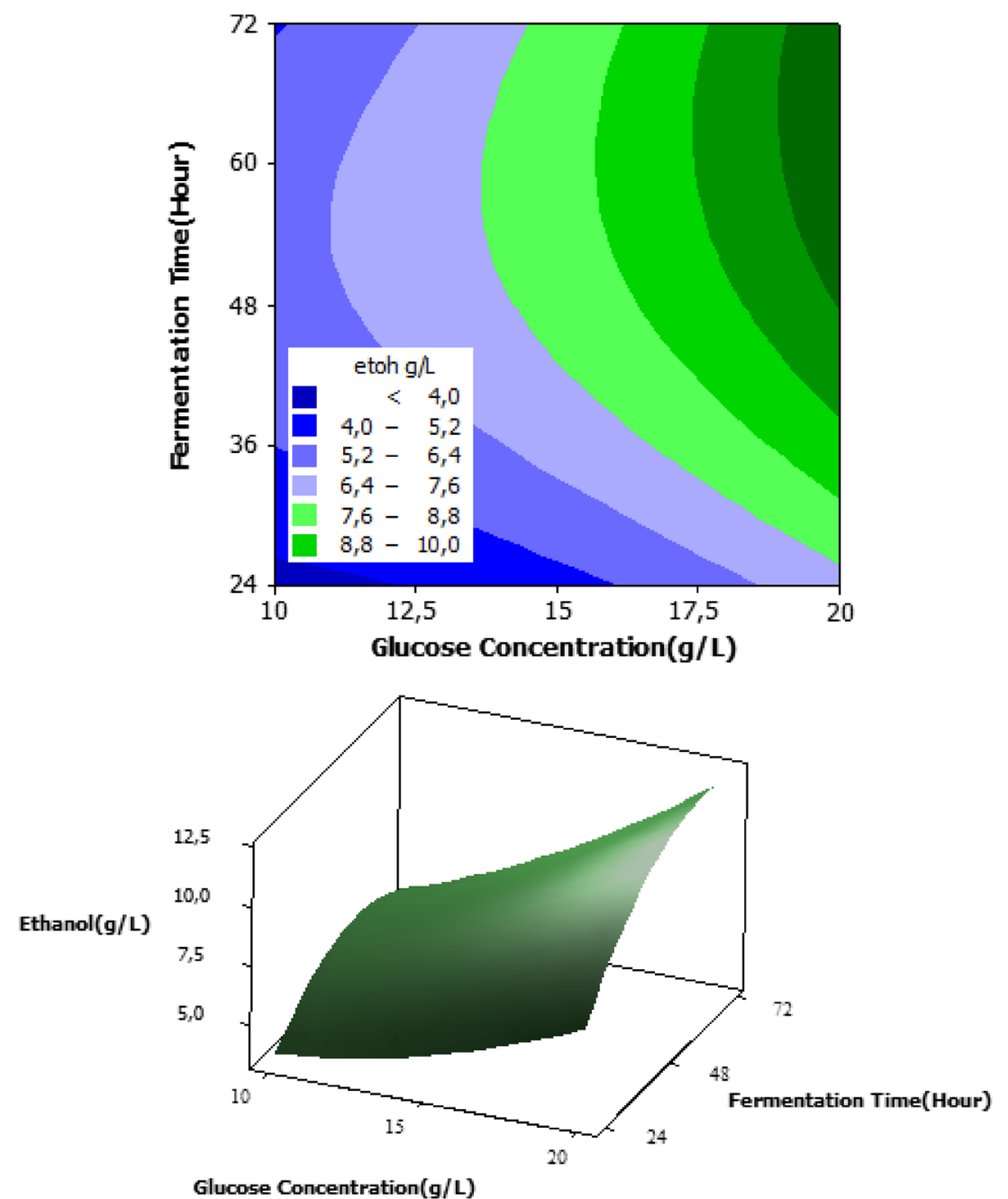

The response surface of the ethanol yield obtained from the quadratic form is given in Fig. 4. The response surfaces as indicated in Fig. 4 reveals the high levels of reducing sugars concentration and fermentation time tend to augment the ethanol production. The increase of reducing sugars concentration at the highest value $\left(20 \mathrm{~g} \mathrm{~L}^{-1}\right)$ and fermentation time $(72 \mathrm{~h})$ enhances the ethanol production from 3.55 to $9.85 \mathrm{~g} \mathrm{~L}^{-1}$. The increase of initial reducing sugars concentration to enhance ethanol production can be explained by the availability of more carbon source, i.e., glucose, to be utilized by yeast ( $S$. cerevisiae) to produce ethanol.

\section{Conclusion}

The potential application of durian seed was as a new resource for bioethanol production was explored in this study. Subcritical water process was employed to convert the durian seed starch into glucose. Time, temperature, pressure, and solid to water ratio were examined as factors that might affect yield of glucose using CCD. Pressure has no significant effect on the yield of glucose. The increase of glucose concentration and fermentation time enhanced the bioethanol production. The optimized values for subcritical water process to produce reducing sugars were achieved at $139.8{ }^{\circ} \mathrm{C} ; 1: 30$ solid to water ratio; and reaction time of $3.58 \mathrm{~h}$ with $32.37 \%$ reducing sugars yield. The fermentation of $20 \mathrm{~g} \mathrm{~L}^{-1}$ reducing sugars for $72 \mathrm{~h}$ results the highest ethanol concentration, i.e., $9.85 \mathrm{~g} \mathrm{~L}^{-1}$.

Authors' contributions AP and YAWY conducted the hydrolysis and fermentation experiments and performed the statistical analysis, JNP and ATN conducted the revision of manuscript, WI drafted the manuscript, SI performed the experiment design and corrected the manuscript.

\section{Compliance with ethical standards}

Conflict of interest The authors declare that they have no competing interests. 
Open Access This article is distributed under the terms of the Creative Commons Attribution 4.0 International License (http://crea tivecommons.org/licenses/by/4.0/), which permits unrestricted use, distribution, and reproduction in any medium, provided you give appropriate credit to the original author(s) and the source, provide a link to the Creative Commons license, and indicate if changes were made.

\section{References}

1. Ajanovic A (2011) Biofuels versus food production: does biofuels production increase food prices? Energy 36:2070-2076

2. Ravindranath NH, SitaLakshmi C, Manuvie R, Balachandra P (2011) Biofuel production and implications for land use, food production and environment in India. Energy Policy 39:5737-5745

3. Sims REH, Mabee W, Saddler JN, Taylor M (2010) An overview of second generation biofuel technologies. Bioresour Technol 101:1570-1580

4. Brennan L, Owende P (2014) Biofuels from microalgae-a review of technologies for production, processing, and extractions of biofuels and co-products. Renew Sustain Energy Rev 14:557-577

5. Saxena RC, Adhikari DK, Goyal HB (2009) Biomass-based energy fuel through biochemical routes: a review. Renew Sustain Energy Rev 13:167-178

6. Vermerris W, Abril A (2015) Enhancing cellulose utilization for fuels and chemicals by genetic modification of plant cell wall architecture. Curr Opin Biotechnol 32:104-112

7. Dutta S, Pal S (2014) Promises in direct conversion of cellulose and lignocellulosic biomass to chemicals and fuels: combined solvent-nanocatalysis approach for biorefinery. Biomass Bioenergy 62:182-197

8. Xie S, Syrenne R, Sun S, Yuan JS (2014) Exploration of Natural Biomass Utilization Systems (NBUS) for advanced biofuelfrom systems biology to synthetic design. Curr Opin Biotechnol 27:95-103

9. Dragone GM, Fernandes BD, Vicente AA, Teixeira JA (2010) Third generation biofuels from microalgae. In: Méndez-Vilas A (ed) Communicating current research, technology education topics in applied microbiology and microbial biotechnology, pp 1355-1366

10. Soccol CR, Vandenberghe LPDS, Medeiros ABP, Karp SG, Buckeridge M, Ramos LP, Pitarelo AP, Ferreira-Leitão V, Gottschalk LMF, Ferrara MA, Bon EPDS, Moraes LMPD, Araújo JDA, Torres FAG (2010) Bioethanol from lignocelluloses: status and perspectives in Brazil. Bioresour Technol 101:4820-4825

11. Affuso E, Hite D (2013) A model for sustainable land use in biofuel production: an application to the state of Alabama. Energy Econ 37:29-39

12. Rathmann R, Szklo A, Schaeffer R (2010) Land use competition for production of food and liquid biofuels: an analysis of the arguments in the current debate. Renew Energy 35:14-22

13. Achten WMJ, Trabucco A, Maes WH, Verchot LV, Aerts R, Mathijs E, Vantomme P, Singh VP, Muys B (2013) Global greenhouse gas implications of land conversion to biofuel crop cultivation in arid and semi-arid lands-lessons learned from Jatropha. J Arid Environ 98:135-146

14. Börjesson P, Tufvesson LM (2011) Agricultural crop-based biofuels-resource efficiency and environmental performance including direct land use changes. J Clean Prod 19:108-120

15. Wua M, Demissie Y, Yan E (2012) Simulated impact of future biofuel production on water quality and water cycle dynamics in the Upper Mississippi river basin. Biomass Bioenergy 41:44-56

16. Subhadra B, Edwards M (2010) An integrated renewable energy park approach for algal biofuel production in United States. Energy Policy 38:4897-4902

17. Alonso DM, Bond JQ, Dumesic JA (2010) Catalytic conversion of biomass to biofuels. Green Chem 12:1493-1513

18. Alvira P, Thomás-Pejó E, Ballesteros M, Negro MJ (2010) Pretreatment technologies for an efficient bioethanol production process based on enzymatic hydrolysis: a review. Bioresour Technol 101:4851-4861

19. Taherzadeh MJ, Karimi K (2008) Pretreatment of lignocellulosic waste to improve bioethanol and biogas production. Int J Mol Sci 9:1621-1651

20. Fanglei Z, Cunwen W, Weigou W, Zhao Y, Faquan Y, Yuanxin W, Ruan C (2011) Effect of alcohol on cellulose hydrolysis in super/subcritical alcohol-water mixtures. Int Conf Mater Renew Energy Environ (ICMREE) 1:548-551

21. Zhu G, Xiao Z, Zhu X, Yi F, Wan X (2013) Reducing sugar production from sugarcane bagasse wastes by hydrolysis in subcritical water. Clean Technol Environ Policy 15:55-61

22. Zhu G, Zhu X, Fan Q, Wan X (2011) Production of reducing sugar from bean dregs waste by hydrolysis in subcritical water. J Anal Appl Pyrolysis 90:182-186

23. AOAC 969.39-1970, Glucose in corn syrups and dextrose products - Glucose Oxidases Method

24. Persson JA, Wennerholm M, O'Halloran S (2008) Handbook for Kjeldahl digestion, 4th edn. CA Andersson, Malmoe

25. Miller GL (1959) Use of dinitrosalicylic acid reagent for determination of reducing sugar. Anal Chem 31:426-428

26. Anwar Z, Gulfraz M, Asad MJ, Imran M, Akram Z, Mehmood S, Rehman A, Anwar P, Sadiq A (2012) Bioethanol productions from rice polish by optimization of dilute acid pretreatment and enzymatic hydrolysis. Afr J Biotechnol 11:992-998

27. Moreschi SRM, Leal JC, Braga MEM, Meireles MAA (2006) Ginger and turmeric starches hydrolysis using subcritical water $+\mathrm{CO}_{2}$ : the effect of SFE pre-treatment. Braz J Chem Eng 23:235-242

28. Fang Z, Smith RL, Kozinski JA, Minowa T, Arai K (2011) Reaction of D-glucose in water at high temperatures $\left(410^{\circ} \mathrm{C}\right)$ and pressures $(180 \mathrm{MPa})$ for the production of dyes and nano-particles. J Supercrit Fluids 56:41-47

29. Gunawan F, Kurniawan A, Gunawan I, Ju YH, Ayucitra A, Soetaredjo FE, Ismadji S (2014) Synthesis of biodiesel from vegetable oils wastewater sludge by in situ subcritical methanol transesterification: process evaluation and optimization. Biomass Bioenergy 69:28-38 